\title{
State-legal regulation of foreign economic and domestic economic activity of the agricultural and industrial complex of Russia
}

\author{
Alexander Suhanov ${ }^{1, *}$ \\ ${ }^{1}$ Institute of Service and Entrepreneurship (branch) of DSTU in Shakhty, Shevchenko str., 147, \\ Shakhty, 346500, Russia
}

\begin{abstract}
The development of a dynamic and competitive global economy modifies the coordinate system of modern foreign economic activity, focusing it on the development and production of innovative hightech agro-industrial products. The article provides a brief overview of the main legal approaches to assessing the effectiveness of innovative foreign economic and domestic economic activity of Russia. The conclusions set out in the publication contain a number of proposals to optimize the instruments of state legal regulation of the policy of the Russian state in the system of implementation of import substitution in the agro-industrial complex. The work substantiates the strategic priorities of the development of the national AIC, which make it possible to ensure a stable rate of economic growth by stimulating the investment activity of economic entities, reducing the critical dependence of agricultural producers on imported technologies, which contributes to increasing food security. Based on the analysis of the role of the agro-industrial complex in ensuring an acceptable level of food security, the study notes specific legal forms of state activity aimed at expanding domestic production, transforming the existing mechanism of state regulation and supporting the agro-industrial complex, caused by a change in the existing conditions of the domestic and domestic market in the agricultural sector
\end{abstract}

\section{Introduction}

The development of the agricultural market of Russia, which plays a strategic role, at the turn of the second decade of the XXI century, takes on special importance as part of the phased expansion of anti-Russian economic sanctions by a number of foreign countries. The severity of the problems, as well as the breadth of the measures and tools used to regulate the agricultural market depends on the state of the economy as a whole, and its agricultural sector, as well as on the role of agricultural producers in ensuring the food security of the state [1]. Therefore, the study of ways to improve the efficiency of the system of public legal regulation of agriculture is now a very urgent problem. The relevance, significance of the presented study is growing and the absence of a sufficiently

*Corresponding author: aspirantsuhanov@rambler.ru 
tested concept of a systematic economic assessment of state-legal stimulation of agricultural development.

The study is based on the work of leading foreign scientists and specialists on the problems of state-legal regulation of the external and internal economic activities of the agro-industrial complex, as well as on the state of food security of the state. Such works include extensive scientific research by $\mathrm{H}$. Cochet, D. Byerlee, A. Bekturganova, K. Deininger, C. Dupraz, G. Graddy-Lovelace, A. Ioris, L. Yerkinbayeva, B. Klimek, D. Labbé, W. Moon, A. Postolle, A. Palliere, H. Hansen, and a number of other equally prominent scientists.

The concept of scientific research is based on an attempt to form a holistic idea of the essence of the agri-food sector as an important subsystem of the national economy. At the same time, scientific novelty consists in the presentation of new theoretical and methodological provisions and the development of important practical tools for the effective functioning of this subsystem in the conditions of the integration effect of environmental factors on the agro-industrial complex. On the basis of a deep analysis of foreign economic and legal literature, additions to the theoretical and methodological basis for the formation of a system of principles of state regulation of foreign economic activities in the agro-industrial complex are proposed using elements of the concept of adaptive design management in order to eliminate imbalances in the development of meso-level systems and localize external negative effects on food security in Russia.

The above circumstances emphasize the importance of the major task being solved in the study, which consists in substantiating the promising directions for the development of the agro-industrial complex during foreign economic activity, by improving the existing mechanism of state legal influence on market participants. At the same time, the importance of applying measures of legal regulation of foreign economic activity of the agricultural market, and the full implementation of tactics and strategy for regulating the functioning of the agro-industrial complex in the conditions of the implemented import substitution policy is clear and quite obvious.

\section{Purpose of the study}

The purpose of the study is defined as the justification of promising directions of development of domestic and foreign economic activity of economic entities of the agroindustrial sector by improving legal regulation mechanisms to ensure the international competitiveness of the Russian agro-industrial complex based on the modernization of state support tools, using the best foreign practices for regulating this activity, as well as improving the unified agro-industrial policy of the Russian Federation in the long term.

\section{Research methods}

The validity and validity of the scientific study is ensured by a holistic, integrated approach, the adequacy of the methods of research of its purpose, as well as scientific testing of the main provisions. The novelty of the proposed proposals is confirmed by the use of a number of modern methods of scientific knowledge, including: analysis of dynamic series, econometric and mathematical modeling, expert assessments, strategic planning, methods of system-structural, technical-legal and functional analysis. Based on the laws of dialectics, it was possible to apply a systematic approach to the main topical issues outlined in the study. 


\section{Research issues}

In the context of import substitution, with the constant threat of political and economic sanctions, the problems of sustainable and effective development of the agro-industrial complex are becoming more and more urgent. State support, among other factors, contributed to the gradual achievement of stable economic growth in agriculture.

So, compared to 2000 , the volume of agricultural production almost doubled, the production of cereals, sugar beets, greenhouse vegetables, livestock, and poultry increased. For example, pork production in 2017 was twice as high as in 2000 and amounted to 4.5 million tons, poultry meat was produced 5.5 times more than 6.5 million tons. In general, at the end of 2017, agricultural and food exports grew by $15 \%$ and reached 20 billion US dollars. The production of greenhouse vegetables increased by $34 \%$ compared to 2015 (the gross collection of greenhouse vegetables amounted to 952.6 thousand tons), the annual growth in the laying of gardens is about 15 thousand hectares.

However, and we cannot fail to note this fact that there remains a significant degree of dependence of agricultural production on the import of tribal, planting seed material. Thus, about 10 million tons of seeds of agricultural plants are sown annually in the Russian Federation, of which about $48 \%$ are maize seeds of foreign breeding (including $40 \%$ imported from abroad); sugar beets - about $96.6 \%$ (of which $8 \%$ are mined in the Russian Federation).

By the way, over the past ten years, Russian exports of these crops have been increasing. In 2010-2019, barley exports grew (in value) 4 times (in physical terms -2.5 times), corn - 13 times, both in value and weight. The geography of grain supplies is also expanding - the level of geographical diversification of Russian grain exports will double (from 6.2 in 2010 to 12.6 in 2019). In the 2019, Russia supplied wheat to 96 countries (in 2010 - to 53 countries), barley to 33 countries (in 2010 - to 23 countries), corn to 33 countries (in 2010 - to 13 countries). A significant increase in supplies over the past decade is associated both with an improvement in the quality of Russian grain (primarily soft wheat) while maintaining competitive prices, and with the work carried out by the Russian side to certify exported products to the markets of importing countries (data on Russia's import of agricultural products in 2019 are shown in diagram 1).
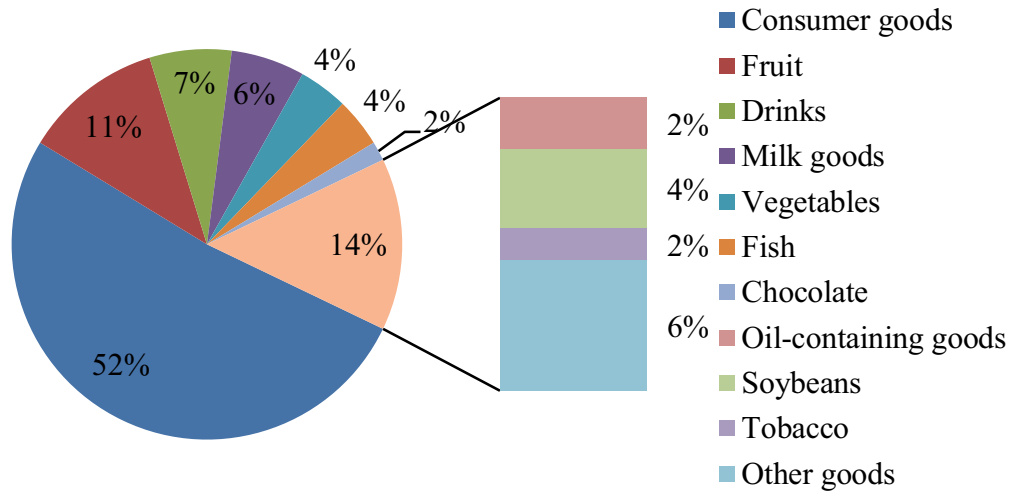

Fig. 1. Russian imports of agro-industrial products in 2019, US \$ billion, Source: https://www.economy.gov.ru.

The Middle East (including Turkey, Iran, Saudi Arabia) remains the key market for Russian grain products. In addition, Russian exports of meat and by-products in 2019 increased by $44.4 \%$ compared to 2018 , reaching a record US $\$ 0.59$ billion. In physical terms, exports grew at a slower pace - by $16.9 \%$ by 2018 to 340 thousand tons. According 
to the results of 2019, the export of processed food products amounted to 9.0 billion US dollars. In the structure of food exports, its share increased from $30.6 \%$ in 2018 to $36.4 \%$ in 2019. Sunflower oil exports in 2019 increased by $37.1 \%$ by 2018 .

Within the framework of the Federal scientific and technical program for the Development of Agriculture for 2017-2025, approved by Decree of the Government of the Russian Federation dated August 25, 2017 № 996, budget support for agricultural production in current economic conditions is a key condition for the development of the industry. This is due to the fact that Klaus Deininger and Derek Byerlee rightly note that agrarian transformations are gradually changing the structure and quality of socio-economic relations in agricultural production, transforming the economic mechanism of economy, including changing property relations [2].

However, along with positive results in the field of agribusiness, negative trends persist. The financial condition of many agricultural industries is in poor condition, material and technical support is reduced, and production and rural social infrastructure often degrades. At the same time, there is undeniable evidence that sustainable agricultural development is possible only with a balanced approach to the implementation of such support measures, including in terms of regulatory regulations. But this balance today, unfortunately, is absent[3].

In our opinion, the state-legal regulation in the field of agro-industrial production in the light of new tasks should be based on the following principles: priority development of agro-industrial production; protection of agricultural producers; preventing direct interference by State authorities in the activities of agricultural organizations; independence in carrying out production and economic activities. These steps, as a result, will allow each state program to harmoniously fit targets for rural territories, redistribute funding from the federal to regional budgets in accordance with the real needs of the rural population.

However, maintaining the policy management of the AIC economy without sufficient material and technical resources from the state is one of the objective reasons that impede the positive development of agrarian relations in the field of foreign trade in AIC goods [4]. At the same time, the reality of the current market is that a significant part of the enterprises of the agro-industrial complex provides only simple reproduction, gradually becoming unprofitable. The subjective reasons for the collapse and disintegration of farms are the low level of leadership, inability, and sometimes unwillingness to adapt to the new economic conditions. Unprofitable farms are a heavy burden for the state economy. They consume resources, they are subsidized from the budget, as a rule, at the expense of well-functioning enterprises. At the same time, the former cannot create competitive products, as a result, they do not fit into the new economic environment.

Currently, the state-legal regulation of the agro-industrial complex is carried out mainly by supporting the existing state of agriculture. However, there is little innovation in agricultural support mechanisms $[5,6]$. Thus, the impact of the private sector on the country's agro-industry is still very weak. The public-private partnership mechanism in this area is practically not used. There is also a small share of agricultural research. Meanwhile, modernization of all spheres of the agro-industrial complex would solve many economic problems of agriculture. As Garrett Graddy-Lovelace and Adam Diamond correctly noted in their work, the State should not be a risk factor for entrepreneurs and should not create new problems for them. Regulation should be aimed at streamlining, stabilization and translation [7].

That is, the legal regulation of agriculture should ultimately contribute to the establishment of order in the regulated sphere, contribute to the balance of interests of all participants in legal relations and be aimed at the timely modernization and development of the entire agro-industrial complex. Thus, one of the most important conditions for the development of the agro-industrial complex of Russia is an adequate change in legislation 
that contributes to the development of measures of economic and legal regulation of agriculture in accordance with macroeconomic conditions, market development features and world trends.

\section{Results of the research}

A legal framework is a system of legal means of influencing public relations. An analysis of the legal framework allows us to determine how law actually affects public relations, how it regulates a particular sphere of public life. A legal framework is a model for the operation of law that reflects the effects of ideal legal constructions on actual practice.

Thus, by describing the mechanism of legal regulation of the agro-industrial complex, it will be possible to see how the rules of law affect this area and answer the question of how effectively this impact is carried out. The mechanism of state-legal regulation of the agroindustrial complex includes the entire array of law norms (including sectoral) governing this area. Thus, agriculture in the Russian Federation is regulated by the norms of the Constitution of the Russian Federation, federal laws, acts of the President of the Russian Federation and the Government of the Russian Federation, as well as a huge number of bylaws issued by ministries and departments involved in the implementation of the country's agro-industrial policy.

The main tasks of the legislator in the field of regulation of the agro-industrial complex are to ensure a balance of public and private interests, and an analytical forecast of all decisions made by the legislator. Since agriculture is very sensitive to external variables (climate, weather, soil conditions, etc.), rash legal policies can permanently disable the entire mechanism of agricultural regulation.

The most important role in regulating the agro-industrial complex is assigned to the Ministry of agriculture of the Russian Federation (hereinafter - the Ministry of agriculture of Russia), the federal executive body responsible for conducting a unified agro-industrial policy. The Ministry of agriculture of Russia organizes its activities on the basis of the Constitution of the Russian Federation, federal legislation and by-laws, the most important of which is the Regulation on the Ministry of agriculture of Russia. This Regulation defines the legal status of the Ministry, its powers and the procedure for interaction with other State authorities.

The Ministry of agriculture of Russia, in order to carry out the functions entrusted to it, takes a legislative initiative regarding the adoption of laws and other regulatory acts, and also independently adopts regulatory acts regulating legal relations in the field of agriculture. The Ministry of agriculture of Russia accepts and implements programs in the field of the agro-industrial complex, and in general implements regulatory, organizational and other regulation of the field of agriculture.

The state legal regulation of the agro-industrial complex is carried out not only by the Ministry of agriculture of Russia, but also by the Ministry of natural resources and Ecology of the Russian Federation (hereinafter - the Ministry of natural resources of Russia). This Ministry is responsible for the regulation of environmental management. The entire sphere of agro-industrial complex operates on the basis of natural resources, therefore, the regulatory impact of the Ministry of natural resources of Russia is a necessary condition. It is the Ministry of natural resources that establishes standards, requirements and restrictions on environmental management, which together allow us to maintain the stability and reproduction of natural resources. The Ministry of economic development also has a certain impact on agribusiness, since it is economic and legal mechanisms that together contribute to the stability of the industry.

For example, in February 2020, by order of the Ministry of Agriculture of Russia, the conceptual foundations of the national platform «Digital agriculture» were developed as 
part of a corresponding departmental project. According to the developer, the concept assumes that the platform will include six under platforms in such areas as land use and land management, industry data collection, product traceability, agrometio forecasting, etc.

In order to increase the turnover of the Russian Federation with foreign partners (including increasing Russian exports), creating favorable conditions for Russian companies to enter international markets, implementing joint projects, lifting trade barriers and attracting investment with foreign countries (excluding CIS, ASEAN and Japan) 89 intergovernmental commissions on trade, economic, scientific and technical cooperation between the Russian Federation and foreign countries (hereinafter - IASC) have been established and are functioning.

In 2019, the Ministry of Economic Development of Russia continued to work to strengthen trade and economic cooperation in Russia. So this year 53 meetings of the IASC were held. At the same time, bilateral strategic documents in the field of cooperation with foreign countries continue to be developed. In 2019, joint work was actively carried out by relevant ministries and departments of the Ministry of Economic Development of Russia to eliminate trade restrictions for Russian exports, and activities were actively carried out to identify barriers that have a negative impact on the access of Russian exports of agroindustrial goods to foreign markets.

The Ministry of economic development of Russia, together with the Ministry of Industry and trade of Russia, ensures participation in all protective investigations of third countries affecting the interests of Russian exporters. During the meeting of the Council of Heads of government (Prime ministers) of the SCO member states (november 1-2, 2019, Tashkent, Uzbekistan), a new version of the Program of multilateral trade and economic cooperation of the SCO member states for the future until 2035 was approved, which is the basic document for further expanding economic cooperation within the framework of the SCO. Following the meeting of ministers of the SCO member states responsible for foreign economic and foreign trade activities (September 26, 2019, Tashkent), the draft Concept for cooperation of the SCO member states on the Development of remote and rural territories in the Digital age developed by the Russian side was approved.

It is thanks to the effective work of Russian experts under the auspices of the Ministry of Economic Development of Russia that the CIS Economic Development Strategy for the period until 2030, which is the main economic document for 10 CIS member countries for the next 10 years, was developed and prepared for signature (the Strategy was approved at a meeting of the Council of heads of Government of the CIS on May 29, 2020). At a meeting of the Council of heads of government of the CIS (October 25, 2019 (Moscow), the Concept of cooperation of the CIS Member States in the field of digital development of society and a plan of priority measures for its implementation were approved. The adoption on June 3, 2019 of the Action Plan for 2019-2020 on the implementation of the Memorandum between the CIS Executive committee and the Eurasian economic commission on in-depth cooperation in the framework of trade activities in the sphere of agro-industrial complex was a step towards the interface of different levels of integration processes, the convergence of legal norms of the CIS and the EAEU.

For example, according to the results of 2019 and 2020, more than 100 regulatory legal acts were analyzed, according to which agricultural subsidies are provided in member states, expert consultations were held on the site of the current commission in relation to certain legislative norms. The report on the results of monitoring in 2019 was approved at a meeting of the Board of the Commission on April 7, 2020 and sent to the governments of member states for use in the work.

Currently, cooperation on strengthening foreign trade relations in the field of agroindustrial complex is carried out on the basis of the protocol on the extension of the Memorandum of Understanding between the Eurasian Economic Commission VI of the 
FAO of November 8, 2018 VI Action Plan for 2019-2023 between the FAO EEC VI, approved by Order of the EEC College of May 21, 2019 № 90. In terms of the development of the seed sector, FAO promotes the involvement of experts of the International Union for the Protection of Plant Varieties, the Organization for Economic Cooperation and Development of the VI International Association for Seed Quality Control in the preparation of proposals and recommendations for improving the legislation of the EAEU member states in the field of testing varieties and seed production of agricultural plants based on international requirements. On December 13, 2019, an agreement was reached on establishing mutually beneficial cooperation in the field of international grain trade and preparing a draft Memorandum on cooperation between the Commission and the MRZ. The purpose of the document is to establish business international ties and strengthen the international cooperation of the Commission with the MRZ in the field of international grain trade, exchange of experience. Cooperation is carried out on the assessment and management of food safety risks, the organization of mutual deliveries of agricultural products, as well as on the genetics and breeding of farm animals on the basis of the Memorandum of Understanding between the Eurasian economic commission and the Government Secretariat on cooperation in the field of the agricultural industry, signed on August 1, 2019 in Buenos Aires. As part of the implementation of the BRICS Economic partnership strategy, during the Brazilian presidency in 2019, work was actively carried out to develop cooperation on supporting the multilateral trading system; micro-, small and medium-sized businesses; investment promotion; the development of electronic commerce; intellectual property; technical regulation, standardization, metrology, conformity assessment and accreditation.

\section{Discussion of the results}

Modern agriculture and the agricultural market as a whole face a large number of various problems, therefore, a balanced mechanism of legal regulation of agricultural relations aimed at foreign economic activity plays a key role in the framework of regulation of these relations [8]. The mechanism for the legal regulation of the agro-industrial complex and its relations with it includes the entire array of norms of international and domestic legislation governing this area.

In modern conditions, the stabilization and effective development of the Russian agroindustrial complex is impossible without state support. The theory and practice of a market economy demonstrates the situation in which the agricultural food sector is most susceptible to negative exogenous influences, which makes government regulation of this sector inevitable $[9,10,11]$.

Turning its attention to the agrarian sphere of the economy, the latter is the subject of joint responsibility of federal and regional authorities. In accordance with current legislation, the subjects of the Russian Federation develop agro-industrial complex development programs, participate in the implementation of federal programs on the basis of agreements with the Ministry of agriculture of Russia. The federal target programs include economic mechanisms that stimulate the participation of regions in solving tasks within the framework of foreign economic activity. Solving these problems for the agroindustrial complex will allow to more fully realized the entire potential of economic growth, to increase the sustainability of development, both of individual agro-industrial enterprises and the industry as a whole.

Improving the efficiency of agricultural production in Russia is a strategic task of the ongoing agrarian reform, the goal of which is the stability of the country's food security. It should be noted that the level of food security depends primarily on the existing potential of the agricultural market. Often, achieving acceptable significance requires changing existing 
development priorities, as well as existing mechanisms for implementing agrarian policy, including its foreign economic component. In addition, Russia is currently actively working within the World trade organization to improve the legal framework of the multilateral trading system, taking into account modern trends in world trade. The consensus of developed and developing States reached in the Doha Round of multilateral trade negotiations of WTO and the adoption of a package of agreements affecting the regulation of the agro-industrial sector pose a problem for the member States of the Eurasian economic union to bring foreign economic policy and regulatory mechanisms of the agroindustrial complex into line with WTO norms and principles [12, 13, 14].

Moreover, we note that the development of economic entities of the agro-industrial complex of the Russian Federation is characterized by the presence of a close connection between the production process and foreign economic activity, the formation of which contributes to the rational provision of food products and agricultural raw materials of the constituent entities of the Russian Federation. A feature of business conditions is the need to protect the domestic production market by improving the applied measures of state influence on entrepreneurial structures. The search for potential opportunities of agroindustrial complex economic entities for effective foreign economic activity is complicated by the need for constant adaptation to market changes caused by the imposed sanctions, which, in turn, requires the search for priority areas for the development of agro-industrial complex $[15,16]$.

Since government support for the agro-industrial complex of the country is the most important factor in ensuring food security, the optimization of customs-tariff and state policy instruments should be considered as one of the tools in the system of import substitution. In addition, we consider it necessary to develop a set of measures to increase the level of digitalization of agricultural production, to stimulate the introduction into this production of innovative, scientifically sound methods (including soil quality management and precision agriculture) using modern information technologies and software. Sufficient measures for the development of agro-industrial complex can be considered the empowerment of the Ministry of agriculture of the Russian Federation with powers of regulatory regulation in the field of labor protection. In addition, it is necessary to develop proposals for a number of additions to regulatory acts in terms of priority provision of state, organizational and other stimulating support to enterprises of the agro-industrial complex participating in the social partnership system, so that scientific organizations in the field of agro-industrial complex can be classified as recipients of subsidies in the framework of the implementation of existing state programs. And also to approve within the framework of regional programs additional mechanisms for stimulating economic entities from regional budgets when paying for targeted student education in order to train personnel for the agroindustrial complex, aimed at the subsequent employment of young specialists in the countryside. Given the unacceptably low level of socio-economic development of rural territories, the decrease in the number of rural populations, it is advisable to develop a single state program of the Russian Federation for the development of rural territories, including measures contained in all sectoral state programs that are planned for implementation in rural territories from 2020 to 2035.

It should be noted that in matters of legal protection of agricultural workers, it is important to improve corporate interpectoral relations, as a result of which the interests of agricultural producers of persons purchasing and selling agricultural products will be balanced. Achieving such a balance will have a positive multiplier effect on both the agricultural sector as a whole and the labor sector in agriculture. Since the agricultural sector is extremely vulnerable and sensitive to price fluctuations, the current «trade discriminatory practices» against agricultural producers have a serious impact on their financial sustainability until the bankruptcy and closure of enterprises. Further 
improvement of trade legislation is therefore essential. So, for example, according to the Ministry of agriculture of Russia, monitoring the implementation of the Federal Law of December 28, 2009 № 381-FL «On the Fundamentals of State Trade Activities in the Russian Federation» in terms of changes in the main indicators of trade activities showed that on the part of industry unions (associations) there was an unequivocal position that the regulatory regulation of relations between suppliers of agricultural products and trade networks made it possible to create mechanisms aimed at the civilizational development of trade activities in Russia, and made the relationship between the parties more transparent.

\section{Conclusions}

Firstly, the agro-industrial complex is the largest national economic complex in the country, on the sustainable functioning of which the standard of living and well-being of the population largely depend.

Secondly, the management of agribusiness organizations is the activity of the relevant bodies and officials aimed at the legal regulation of domestic and foreign economic activity, ensuring the effective use of material, labor, financial and natural resources in order to obtain a financial result - profit.

Thirdly, food security, being an essential condition for the sustainable development of the state and a consequence of a «reasonable policy» in the field of agribusiness, is a strategic element of national security as a whole. The special relevance of ensuring its acceptable level is associated with the action of the sanctions regime and the anti-sanctions policy implemented by the Government of the Russian Federation, taking into account active import substitution. But the orientation towards import substitution and related modernization should change the raw materials orientation of the Russian economy. As a result of the action of such an economic and legal link, there is a need to develop measures and tools for effective support of economic entities of the agricultural sector of the economy, including those engaged in direct foreign economic activity.

Fourthly, the intensification of the State's activities to regulate agricultural production today has failed to create an effective mechanism for the development of the agro-industrial complex, and the State legal measures taken often do not have the necessary impact on its condition. This is due to the fact that agriculture cannot participate in intersectoral competition, which is caused by natural and climatic features, the pronounced seasonal nature of work, and the low return on capital. We believe that assessing the state regulation of agro-industrial complex in terms of its legal regulation will help to make a choice in favor of effective economic methods and will be the basis for planning possible short-term and long-term measures for the development of the agro-industrial sector and will determine the results and nature of the regulatory impact on Russia's foreign economic activity in the agro-industrial market.

\section{References}

1. L. Yerkinbayeva, A. Bekturganov, Procedia - Social and Behavioral Sciences 81, 514519 (2013) doi: 10.1016/j.sbspro.2013.06.469

2. K. Deininger, D. Byerlee, World Development 40, 701-714 (2012)

3. R. Whaples, L. Heckelman, American Economist 1, 66-78 (2005) doi: $10.1177 / 056943450504900105$

4. H. Rodrigues, C. Jardén, P. Dorrego, International Journal of Knowledge-Based Development 9, 15-33 (2015) doi: 10.1504/IJKBD.2015.069454 
5. A. Subramanian, V. de Vrande, Journal of Operations Management 96, 517-535 (2019) doi: 10.1002/j00n'1.1045

6. A. Marossi, M. Bassett, Economic Sanctions under International Law (T.M.C. Asser Press, N.Y., 2015)

7. G. Graddy-Lovelace, A. Diamond, Journal of Rural Studies 50, 70-83 (2017)

8. D. Labbé, Cities 53, 150-155 (2016)

9. A. Ioris, Futures 95, 76-85 (2017)

10. W. Moon, Ecological Economics 71, 13-24 (2011)

11. Catherine Dupraz, Angèle Postolle, Food Policy 38, 115-125 (2013)

12. A. Palliere, H. Cochet, S. Leone Land Use Policy 76, 422-431 (2018)

13. K. Deininger, D. Byerlee, World Development 40, 701-714 (2012)

14. H. Bernstein, Agrarian Political Economy International Encyclopedia of the Social \& Behavioral Sciences (2015)

15. B. Klimek, Henning Otte Hansen, Food Policy 69, 110-122 (2017)

16. U. Malaga-Toboła Sylwester, K. TaborSławomir, Agriculture and Agricultural Science Procedia 7, 158-164 (2015) 